\title{
THE NURSING STUDENT AT THE UNIVERSITY OF SOUTH AFRICA
}

\section{E.B.I. BROWNLEE}

\section{OPSOMMING}

Hierdie navorsing is 'n omvattende studie in die hedendaagse verplecgonderwys met die klem op die onafhanklike benadering tot leer.

Unisa word uitgeken as een van die eerste universiteite in die wêreld om teletuisie in tersiêre onderrig in te stel. Dit is ook die heel eerste universiteit om afstandsonderrig in te stel as nabasiese voortgesette onderrig vir geregistreerde verpletgkundiges op die skaal van die kursusse wat tans deur die universiteit aangebied word.

Verpleegkundiges het vir baie jare met sukses deur Unisa gestudeer, maar het nêrens in Suid-Afrika die geleentheid gehad om hulle professionele studies deur teletuisie in hulle eie dissipline voort te sit nie.

Hierdie studie is ontwerp om vas te stel of Unisa se vertroue in die onderneming geregverdig is. 'n Diepgaande ontleding van verpleegkundiges as studente in hierdie nie-tradisionele leersituasie is onderneem. Aangesien hulle hoofsaaklik werkende studente in 'n essensiële diens is, is hulle werkgewers se probleme, asook die baat wat die betrokke dienste by hulle studies vind, onder die soeklig geplaas.

Daar is bevind dat ten spyte van sekere belangrike probleme, die instelling van verpleegstudies deur UNISA ten volle geregverdig is. Dit word bewys deur die toenemende studentetal, die bevestigte voordele wat aan alle gemeenskappe asook die beroep as 'n gebied toegekom word, en die erkenning van die Westerse wêreld vir hierdie tipe onderrig vir verpleegkundiges.

Verder is bewys dat die meerderheid van huidige verpleegleiers grontendeels hulle akademiese opleiding deur Unisa ontvang. Die beroep is aan hierdie leiers en aan Unisa dank verskuldig vir hulle bydrae tot die voorbereiding van verpleegadministrateurs, -opvoedkundiges en -navorsers in alle kulturele groepe om die ontwikkelende gesondheidsdienste te beman.

\section{INTRODUCTION}

This research project, undertaken in the Department of Nursing Science at Unisa between 1978 and 1981 , focuses on nursing education in general and in particular on nurses as postregistration students furthering their education through the medium of teletuition in the nonresidential academic setting offered by Unisa.

\section{ACADEMIC OPPORTUNITIES FOR NURSES}

University education for nurses first became a reality in South Africa in 1937 when postregistration diploma courses for qualified nurses were introduced by the universities of Cape Town and the Witwatersrand. Further opportunities for academic studies progressed slowly until

E.B.I Brownlee, BA (Unisa), M Cur (UP) D Litt et Phil (Unisa), General Nurse, Midwife, Tutor, Nurse Administrator. This article is based on research undertaken for the degree D Litt et Phil. The author was Associate Professor with the Department of Nursing, Unisa, at the time of the research. Present address: 44 First Ave, Lambton, Germiston.

This article is reprinted from Humanitas, RSA Vol. 9, No. 4, with their permission.
1956, when the long-awaited acceptance of nurses into university for a basic baccalaureated degree in nursing was achieved. In 1966 the University of Pretoria pioneered the establishment of the first Chair of Nursing in South Africa with a nurse as Professor and Head of the Department. By 1981, 14 universities had established Departments of Nursing, through which a variety of Bachelor, postregistration and postgraduate degrees leading to Masters and Doctoral studies, as well as nongraduate diplomas, were being offered in such fields as clinical nursing, nursing administration, nursing education and community health nursing science.

\section{JUSTIFICATION FOR THE INTRODUCTION OF NURSING COURSES AT UNISA}

Despite the progress achieved through these courses, a solution had yet to be found to meet the needs of all communities for an adequate and effective nursing service and to overcome the lack of postregistration nursing education. This became especially urgent in the light of the new Health Act (Act No. 63 of 1977) which proposed a comprehensive health service for all sections of the community, and a reorganisation of health facilities in a network of central, regional and peripheral services which would bring the nurse into the forefront at these levels.' Their comprehensive preparation to enable them to function with optimum efficiency as planners, policy makers, researchers, effective practitioners and leaders demanded that those nurses from the upper echelons of all cultural groups be afforded the opportunity of academic education. However, the problems of the full-time working woman, those with families, the geographical siting of the universities, limited facilities for the different races and the necessity for employers to release large numbers of staff for extended studies, militated against the fulfilment of these ideals through the channels of residential university education. ${ }^{2}$

Many of the nursing educators of the day -- themselves holding degrees in the Arts and Social Sciences from Unisa - were enthusiastic advocates of self-directed independent study, in favour of teletuition. Thus negotiations which led to the establishment of the present Department of Nursing Science at Unisa were commenced between the South African Nursing Association and the University in 1972 and successfully completed in $1975 .^{3}$ 


\section{THE OBJECTIVES OF THE RESEARCH}

To look critically at, and construct profiles of, nursing students at Unisa in a nontraditional teaching and learning situation, namely teletuition.

To highlight the problems, rewards and opinions of the learners and their employers while gathering information for future planning.

To review the students' part contributions to the health services, their levels of achievement and the projected benefits of their learning in providing an improved service.

To evaluate South Africa's concept of continuing education for nurses as offered traditionally and to examine the unique concept of teletuition for nurses in the light of contemporary developments.

\section{METHODOLOGY AND DESIGN OF THE STUDY}

In expoloring these and other issues, a descriptive survey was undertaken with some comparisons being drawn between categories of respondents and different culture groups. Two major target populations were identified, namely the students $-96 \%$ of those in nursing studies were in full-time employment - and their employers.

The research was planned so as to include four distinct categories of students, as follows:

Category 01 (N516) - All the first graduates from the nursing courses in 1978 as well as final-year undergraduates for 1979-1980.

Category 02 (N19) - Postgraduate students registered for Honours', Masters and Doctoral studies with the Department of Nursing Science.

Category 03 (N81) - A group of nurses who had completed academic studies through Unisa before nursing courses were available.

Category 04 (N79) - A group of nurses currently enrolled for studies at Unisa through departments other than Nursing Science.

These last two categories were traced through personal contact or by placement of advertisements in strategic publications. In each of these categories, 106 questionnaires were despatched, with a $77 \%$ return. The second target group representative of the employing authorities - was drawn from the senior ranks of nurses in the state and provincial departments of the Republic, nursing officers of selfgoverning and neighbouring independent states, nursing educators and administrators in charge of nursing colleges and hospitals, and nursing representatives of regional and local authorities in the health services. All these persons were likely to have large numbers of nurses working under their jurisdiction while pursuing Unisa studies.

\section{RESEARCH TECHNIQUES}

These included questioning respondents, colleagues and others by means of mailed apparatus or through face-to-face formal interviews and informal discussion; statistical analysis of data; review of records, reports and other literature. With respondents widely dispersed throughout the Republic, Southern Africa and aboard, mailed questionnaires were used to gather data from the student population - numbering 1044 . The percentage return in different categories ranged from $66,2 \%$ to $79,2 \%$, with a mean of $72,4 \%$. The opinions of employing authorities were obtained through interviews - five through mailed schedules and the remaining 35 through faceto-face structured interviews and informal spontaneous discussions. This volume of predominantly nonquantifiable data was processed manually by the researcher to ensure anonymity.

\section{CONTENT OF THE DATA}

In examining such issues as the feasibility of introducing academic courses for postregistration nursing students through Unisa's methods, the individual and collective rewards which may accrue to students and their employers and the projected long-term benefits for the nursing profession, an in-depth study was undertaken into the students' needs, their motivation for academic study, the courses which they selected, their educational, social and professional backgrounds, their failures, problems and rewards, and the contribution of employing authorities and other professional bodies involved in this venture.

\section{PROCESSING OF DATA}

Data from the students' questionnaires were processed using two programmed packages - Statistical Package for the Social Sciences ${ }^{4}$ and Biomedical Computer Programmes (P Series). ${ }^{5}$ Contingency tables were constructed for discreet groups of respondents, and twogroups and three-groups comparisons were set up between Blacks and Whites, and Black, Afrikaans and English respondents, respectively. It was anticipated that the findings would show up differences in geographical distribution, social and professional background, attitudes and opinions and other variables between the three cultural groups so that certain trends could be identified and profiles constructed. (In all categories, Coloured and Asiatic students were so few (17 in total) that they were not included in the computer analysis, but the data were processed and analysed manually.) Differences were most evident in the large group of undergraduates numbering 516 respondents; with the level of significance set at one per cent, meaningful differences between groups were observed in respect of $65 \%$ of the 48 variables computed. In the remaining three categories of students very little statistical significance was evident owing to the small total number of postgraduates and owing to the disparity in numbers and/or homogeneity between cultural groups. 
Part One provides the purpose and aims of the study, the assumptions underlying the project and the literature supporting these assumptions. It also includes the method of the study. The discussion in Part Two embraces a review of the education system in South Africa and its effect on nursing education, the need for the recognition of nursing education at university level and an overview of basic nursing education leading from postregistration courses to the introduction of nursing at the residential universities.

Part Three is concerned with the nature of Unisa - its methods, its students, its personnel - and the developments leading to the implementation of nursing courses at Unisa. It also includes the growth and development of the student body and the Department itself, the contribution made by the various authorities which have relevance to Unisa courses, a short resumé of the independent learning approaches in other countries, and a graphic presentation of the progression in the rate of preparation of nursing educators, administrators and community health nurses through the residential courses and, over the past three years, through Unisa. This section is concluded with an analysis of the problems and opinions of the employing authorities and the preceptors and their contribution to the implementation of the courses in the practical field. Part Four is devoted to a searching analysis of the various categories of nursing students who are currently engaged in studies in nursing or other disciplines or who have completed academic study through Unisa and elsewhere in the past. From this latter group a cadre of nurse leaders has emerged; these nurses prepared themselves through independent study before nursing education was introduced to the universities, and are now ranked among the acknowledged leaders of the profession. Part Five, the final section, is concerned with the appraisal of the research; it illustrates that the objectives have been met and that the assumptions and hypothetical basis of the study have been supported by the findings.

\section{FINDINGS AND CONCLUSIONS}

The nature of the data meant that no clearly defined hypothesis could be formulated, but the hypothetical basis of the research rested on an attempt to justify the introduction of nursing degrees/diplomas at Unisa and to evaluate whether they are adequately fulfilling a need in the nursing profession. The conclusions indicate that the objectives were met and that the asumptions and hypothetical basis of the study were supported by the findings. Due to the volume of valuable information acquired from the data, it is not possible to present all the findings and conclusions from each section of the report. Accordingly, a selection of the main findings are highlighted below

On the question of the suitability of teletuition as a valid method of continuing education for nurses, it was shown that nurses - in particular those with previous academic experience - can attain a high degree of success although independent learning poses many problems for a considerable number of students. Inability to master the study methods and course content was consistenly evident in a proportionately larger number of Black students, as shown by their comments, their higher failure rate and the statistical analysis which revealed a greater concentration of significant factors hampering their progress.

The conclusion was drawn that Unisa's method is a valid and viable proposition for a varying proportion of nurses of all groups.

A second question to be addressed - whether Unisa courses were adequately fulfilling a need was answered by the students themselves; the greater majority agreed that their personal needs were being met in nursing and non-nursing programmes, while the consensus from the employing authorities was that the profession must benefit from the knowledge and skills of the graduates in time.

The figures depicting the increase in the registration of additional qualifications indicate further that the deficit is being made up since the establishment of the Unisa courses.

In providing opportunities for all race groups to further their education at university level, the Unisa courses have most certainly met an urgent need in the case of Black nurses, who historically have not had the same opportunities offered to Whites.

University nursing education has been placed within reach of all registered nurses who otherwise could not have enjoyed the privilege.

The discussions on the education system and the overview of nursing education revealed that the lack of facilities, in the form of sufficient schools, adequately trained teachers and suitable subject choices in the curricula for girls adversely affected the thorough preparation of nurses for university level.

Not until after the 1970s, when 12 years of schooling could be effectively introduced as a requirement for admission to registered nursing training, could sufficient potential graduates be prepared at the universities where facilities were available.

The fact that the colleges of nursing do not carry the same status educationally in law as the technikons and the colleges of education, further precluded the implementations of the "College idea" advocated by the Van Wyk de Vries Commission.

From the findings of Part Three it appears that Unisa is making a singular contribution in the preparation of enlightened and academically educated nursing leaders to man the health services and to staff the nursing departments of the emerging Black universities and others.

Many factors in the analysis of the undergraduate students led to the conclusion that the working student completed her studies under very difficult circumstances.

While over $70 \%$ of all undergraduates were in full-time employment, had family responsibilities and a theoretical and practical study commitment, the Black undergraduate students had a heavier domestic commitment.

Of the total undergraduate group, $85 \%$ omitted to make use of the advice available from official 
sources and in an effort to complete their studies in the shortest possible time, many students undertook far too heavy study loads to the detriment of their work, their families, their studies and their own health.

Of the Black student group $78 \%$ versus $3,5 \%$ of White students repeated between one and three courses at some time, while the overall failure rate of the Black students was consistently higher than that of White students over the three years under consideration.

It is concluded from the above that these students either underestimate the complexity and depth of the study material or overrate their own ability to cope adequately with the demands of work, family and studies.

Of the total undergraduate and postgraduate students $90 \%$ indicated their intention to continue their studies to advanced postgraduate level through Unisa.

In the postgraduate group, the 19 respondents already held 24 degrees before registering for postgraduate studies at Unisa, whereas of the 81 respondents from the early graduates, 41 had been awarded a total of 51 subsequent degrees in addition to their first degree acquired through Unisa - 19 at Master's level and four at Doctoral level, while $66 \%$ of these respondents had completed one, two or three postregistration courses before registering their first degree.

In these groups of highly educated nurses their belief in the concept of lifelong learning is clearly evident as is the widely felt need for a broader spectrum of knowledge and the realisation that they must keep abreast of developments in nursing

Of the 79 respondents who had been currently studying for nonnursing degrees, $72 \%$ were English-speaking, $69 \%$ being the wives of professionals. Of these, $47 \%$ were not working and $20 \%$ were employed in non-nursing posts. In the total group of respondents, $75 \%$ were reading for a degree in Arts.

From the comments of the English group it appears that they were seeking mental stimulation in a non-challenging role as housewives, while the Black and Afrikaans students were nearly all employed in nursing posts and undertaking their studies with a view to finding other employment or broadening their academic background.

Finally, although there do not seem to be any programmes in nursing comparable with those offered by Unisa, the need for independent learning in nursing education has been recognised and is being met through a variety of self-instructional programmes, off-campus courses and even teletuition in other countries, while international nursing leaders from many parts of the world have shown a keen interest in Unisa's concept of continuing education for nurses.

\section{DESCRIPTIVE PROFILES OF RESPONDENTS}

As the main body of the report focuses on the undergraduate students working in the service areas or in educational institutions, the profiles of these students and the leaders of the profession - many of whom are representative of students' employing authorities - are presented below.

Although it is by no means intended to reduce any individuals unique and different from all others - to an "average", certain similarities and differences do become apparent in groups of persons. This applies to students too. These characteristics enable observers to build up a word picture, an image or a descriptive profile of them.

\section{The Black undergraduate student}

The Black undergraduate student reading for the B.A.Cur. degree in nursing at Unisa is a registered nurse from the Transvaal, between 31 and 40 years of age, employed full time in the curative services of a provincial hospital as a senior sister or sister. She came into the profession with a matriculation exemption which she has probably converted into a university entrance matriculation through private study, has given 15 to 19 years of service to nursing, has the basic qualifications of general nursing and midwifery and at least two postregistration qualifications in either Ward Administration and Clinical Teaching, Nursing Education, Community Health, Nursing Administration or a diploma in the clinical field.

Her social status is determined by the occupation of her father and her husband, both of whom hold positions in jobs falling under the category of one with high social prestige. Her mother is either a housewife and home-maker or is (or has been) a teacher. If she herself has held a job outside the field of nursing it was likely to have been in the teaching profession.

Her husband is regarded as the main breadwinner but she contributes more than $50 \%$ towards household expenses. In the home she cares for 2-3 dependent children and has other dependants living with her in her home. She does, however, have domestic help. She travels less than five kilometres to work daily, has to make use of public transport which, although less expensive than private transport, takes considerably longer. Transport costs her between R10-20 per month.

She estimates the cost of study material and books alone at more than R200 annually and her projected estimate of the total costs of acquiring her degree will be between R1 000 and R1 500. She does not receive a bursary, has no other source of financial assistance and receives no assistance from her employer in the form of finance, transport or extra time off for study. In her final year of study she registered for two nursing subjects (both at the level of major subjects) and one additional subject.

She is an active member of her church group, takes a lively interest in community activities and sport and has several hobbies pertaining to the Arts. Her citizenship potential is high, but she has too little time to attend church activities and, as a mother of schoolgoing children and as a nurse, plays little part in youth activities, civil defence or welfare work. 
In her home, facilities for study with regard to privacy and silence are limited. She lives more than ten kilometres from the nearest suitable library but makes use of the South African Nursing Association library and publications section, libraries of provincial nursing colleges, public libraries and university libraries. Her reasons for embarking on these studies were given as seeking job satisfaction, through improving her knowledge and skills.

Before commencing her studies, she did not seek advice from any official sources, but relied on information supplied by fellow students and peers, from whom, in her opinion, she received satisfactory advice on both nursing and nonnursing subjects. She finds both groups of subjects equally difficult, although they complement each other and she has had to repeat more than one subject. Orientation visits, group discussions and the practical component of the nursing courses were all rated as being of much benefit and the respondents feel that their studies could ultimately prove to be of benefit to their employing authorities, their colleagues, their patients or clients.

Despite the difficulties with which she has had to contend, she has every intention of pursuing further studies through Unisa in the line of postgraduate nursing degrees. Should clinical courses be introduced she would be very interested in this line of study. As far as her future is concerned, she has no intention of changing her job but states emphatically that she will endeavour to perfect her job and is seeking promotion in the field she is in at present

\section{The White undergraduate student}

The profile of the White respondents is based on the characteristics displayed by the Afrikaans students who outnumbered the English by 91. Any specific differences in the English group will be summarised separately.

This student, like her Black colleague, lives and works in the Transvaal. She too is between 31 and 40 years of age, married and employed as a sister or senior sister in the provincial hospital services. She left school with a matriculation exemption and has been nursing for 15-19 years, during which time she has acquired general nursing, midwifery, registration as a tutor and she may well have been a graduate from a basic or postregistration nursing degree.

Her father was an independent farmer, her mother a homemaker or professional woman, and she herself has married a professional man who is the main breadwinner in the family although she contributes more than $50 \%$ to the family expenses. Although she has dependent children, she has no other dependants to be cared for in her home, but she does employ domestic help. Using private transport, she travels five to fifteen kilometres to and from her place of work daily. Although private transport is quicker, it is more expensive and she estimates her travelling costs at more than R20 monthly. She does not receive a bursary, nor any financial help from other sources nor assistance from her employer in the form of extra study time or transport. She estimates that her study material and books cost her more than R200 annually and expects her degree to cost her between R1000 - R1 500.

In her final study year, she registered for two major subjects and one additional subject but can only devote six to ten hours a week to studying. In addition, she attends church services regularly, is a member of two or more community organisations and has many hobbies which are of a domestic nature. She has two to four hours a week to devote to all these activities. Like her Black counterpart, she takes little part in youth activities, civil defence or welfare organisations, although her citizenship potential is high. Facilities for study in her home are quite adequate, but obtaining study material from libraries is a problem. She lives more than ten kilometres from any suitable library, but makes good use of all available facilities and particularly those provided by the South African Nursing Association.
Although she was aware of official sources from which she could have obtained information prior to commencing her studies she, like other students, obtained most of her information from fellow students and found it satisfactory. She states that both nursing and nonnursing subjects are difficult, but she has not had to repeat any subjects. She has found the contact with lecturers in both nursing and non-nursing subjects adequate and of great help and has benefited greatly from orientation, group visits and from the practical part of her studies.

In her opinion she feels that her studies will be of benefit to her colleagues, her employing authorities and her patients. She prefers Unisa's methods to others and intends continuing to postgraduate level and she would be interested in pursuing a clinical course should it be offered. She intends staying in the field in which she is employed, and is hoping for promotion. According to her comments, she found the studies a challenge and enjoyed the challenge.

\section{The White English-speaking respondents}

The profile of this student does not differ very much from that of her Afrikaans-speaking colleague, except that she is older, her age group being between 41 and 50 years. She entered the profession with matriculation, qualified as a general nurse and midwife but not through a basic nursing degree, was more likely to have acquired an additional qualification in the clinical field than in Nursing Administration or Nursing Education, and also to have travelled abroad and completed a study course in the United Kingdom.

Whereas her Afrikaans colleague's father was an independent farmer and her husband a professional man, this student's father was a professional and she had married a man whose occupation is classified as administrative, clerical or civil servant. Her mother, like her collegue's, is a housewife or professional person. 
This student, in her final year, was registered only for her two nursing majors, having completed all her additional subjects. She has not had to repeat any subjects, does intend to study further, but is more likely to pursue her studies in a discipline other than nursing. She does not find UNISA's methods preferable to others she has experienced, did not benefit as much from orientation as her colleagues, but found the group discussions and practica beneficial. In her comments she is much more outspoken than her colleagues and more critical of aspects of the courses that did not satisfy her.

\section{PROFILES OF THE NURSE LEADERS}

\section{The Black nurse leader}

This nurse has risen through the ranks from ward sister to tutor or matron to occupy a senior position as a nurse administrator in the curative services, the college environment or at head office level.

Resident in the Transvaal or Natal, she attended school in a rural area where she showed leadership potential at an early age. She may have had to convert her scholastic status through private study to enable her to enter university. She entered nursing between 17 and 20 years of age and has given 16 to 20 years of service to nursing. During that time she married and in her thirties she registered at Unisa for either a B.A. or a degree in Social Work, while she was in full-time employment. She found Unisa's method difficult and at some stage she had to repeat a year or write a supplementary examination. She had very little time for recreation, could only spare six to ten hours a week for study and always had to use her vacation. In her home she had between three and five persons to care for and as a leader in the community she was actively involved in church affairs and welfare organisations when she had time.

Her husband, who was a professional man (a teacher) was able to assist her with her studies, and she herself was an active member of her professional association. Her interest in the line of hobbies centred on homecrafts, gardening and outdoor sport.

Professionally, she was well qualified, with general nursing and midwifery as a background. She had acquired both a Diploma in Nursing Administration and Education, a non-nursing degree and recently she had completed a nursing degree through Unisa, confirming her belief that the nursing courses are a suitable form of continuing education for nurses although she does not believe all nurses should have a university education at basic level.

She was grateful for the opportunity of studying through Unisa and believes that it is an excellent method of self-development.

\section{The White nurse leader}

The leader among the White nurses, irrespective of whether she comes from an Afrikaans or an English home, has come from the Transvaal, is unmarried, is now over 40 years of age, qualified as a general nurse and midwife through a diploma programme and has given between 26 and 43 years of active service to the nursing profession. If she came from an Afrikaans home she would have received her schooling in a rural area and it is likely that her father was an independent farmer and her mother a homemaker. Her English-speaking colleague whose parents were both professionals or in business was a product of the cities. She left school with a university entrance matriculation having shown ample evidence of leadership potential in various activities at school. She had entered nursing by the time she was 19 years of age and before she registered for her Unisa studies she had equipped herself with one, two or three postregistration qualifications - the majority of both the Afrikaans and English-speaking persons acquiring a tutor's qualification, with a Diploma in Nursing Administration or a clinical course as the second choice of the Afrikaans and English nurses respectively.

Occupying either a teaching post or being directly involved in a clinical or administrative post in which she realised the need for a broader background knowledge, she made use of the opportunities offered by UNISA to acquire a degree while having in many cases, an exacting, demanding full-time job. Taking four to six years, she qualified through a Bachelor of Arts. At this stage she was in the age group 30-39 years, the move to place nursing in the universities was under way, and as one of her colleagues commented, it was realised that a tutor needed to be a graduate. New recruits had opportunities to acquire a degree ... one had to undertake further study to remain on top. She found study through Unisa difficult, and, on account of the nature of her job, had to put in extra hours over and above the 40-48 hour week she had too little time to study and consequently she had to use her vacation for study. Although the acquisition of a degree was not essential for the post she held at the time, she was convinced that it enabled her to cope more effectively with her job. Her opinion was positively in favour of Unisa's courses for nurses although she may have had some reservations about practica and clinical courses. Subsequent to acquiring her first Unisa degree she continued her academic studies either through Unisa or other universities and now has two or more degrees, one of which is likely to be in nursing, and she may well be registered for nursing studies of a postgraduate nature at present. In her professional career, she had moved step by step into the upper echelons of the profession while she had been studying; she appears to be committed to the concept of lifelong learning. At the same time, she had not neglected her community involvement nor her professional commitments, having maintained active membership for periods ranging from 10 to 36 years presenting a very good picture of citizenship. Professionally, her activities are wide ranging both administratively and educationally. She is constantly involved in planning, policy and decisionmaking, has many advisory and educational functions, travels abroad as part of her professional enrichment, is often the main speaker at professional gatherings on local and national level, maintains affiliation

ContInued on p. 37 